\title{
Urdimento
}

Revista de Estudos em Artes Cênicas

E-ISSN: 2358.6958

\section{Agamenon ou - \\ Quanto vale a vida de um homem?}

Juliano Casimiro de Camargo Sampaio

\section{Para citar este artigo:}

SAMPAIO, Juliano Casimiro de Camargo. Agamenon ou - Quanto vale a vida de um homem? Urdimento,

Florianópolis, v. 2, n. 38, ago./set. 2020.

DOI: http:/dx.doi.org/10.5965/14145731023820200018

Este artigo passou pelo Plagiarism Detection Software | iThenticate 


\title{
Agamenon ou - Quanto vale a vida de um homem?
}

\author{
Juliano Casimiro de Camargo Sampaio
}

\begin{abstract}
Resumo
Este texto discute aspectos da criação do espetáculo teatral Agamenon ou - Quanto vale a vida de um homem?, em Palmas (TO), no que se refere às dinâmicas dialógicas a respeito da significação do espaço da encenação e de acompanhamento do público, bem como da memória e do imaginário histórico presentes na composição da obra. Metodologicamente o texto emerge da articulação entre memórias do encenador, dados históricos e sociais que embasaram a criação, imagens de apresentação do espetáculo, trechos da dramaturgia da obra e conceitos teóricos como veio de análise. Resultou da pesquisa que a articulação entre ficção e realidade e a ocupação cênica de espaços de conflitos sociais favorecem a emergência, para além da fisicidade do lugar, de fluxos simbólicos e imaginários desde e sobre o lugar teatral.
\end{abstract}

Palavras-Chave: Teatro. Memória. Imaginação. Espacialidade. Poética.

\section{Agamenon or - How much is a man's life worth?}

\begin{abstract}
This text discusses aspects of the creation of the theatrical show Agamenon or How much is the life of a man? at Palmas (TO). This is done with regard to memory and historical imagery present in the composition of the work. Methodologically, the text emerges from the articulation between the director's memories, historical and social data that supported the creation, images of the show's presentation, excerpts from the dramaturgy of the work and theoretical concepts as it came from analysis. It resulted from the research that the articulation between fiction and reality and the scenic occupation of spaces of social conflicts favor the emergence, in addition to the physicality of the place, of symbolic and imaginary flows from and about the theatrical place.
\end{abstract}

Keywords: Theater. Memory. Imagination. Spatiality. Poetic.

1 Professor Doutor Adjunto na Universidade Federal de Tocantins (UFT), Palmas, TO. Pós-doutor em Educação (UNICAMP). Pós-doutor, Doutor, Mestre em Psicologia (USP). Bacharel em Artes Cênicas (UNICAMP). Juliano.casimiro@uft.edu,br 
Folder

Recordo-me daquela paisagem como se

estivesse vendo uma fotografia. Quintais

espaçosos, areia branca, águas claras do Rio

Tocantins, meninos a gritar.

(Marilucia Abreu Lima²)

Neste artigo partimos de uma experiência de criação em teatro (Site Specific) para se chegar a discussões a respeito dos fluxos simbólicos ${ }^{3}$ e imaginários sobre o lugar, quando se tem interdependência entre espaço real e espaço ficcional na organização dos simbolismos da cena teatral. De partida reconhecemos como válido o pressuposto de que:

Quaisquer que sejam os lugares e os momentos nos quais o teatro acontece, ele sempre se caracteriza por uma tensão entre realidade e ficção, entre o real e o fictício. Pois é sempre em espaços reais e num tempo real que se passam as representações e são sempre corpos reais que se deslocam nestes espaços reais. (Fischer-Lichte, 2013, p. 14).

Partimos de análise de diferentes naturezas de registros (fotos, texto dramatúrgico, anotações de caderno de campo, memórias) do espetáculo teatral Agamenon ou - quanto vale a vida de um homem?, produzido e apresentado por estudantes ${ }^{4}$ da Licenciatura em Teatro da Universidade Federal do Tocantins (UFT),

${ }^{2}$ Lima, 2016, p. 8.

${ }^{3}$ Os fluxos simbólicos são entendidos aqui como as dimensões temporais e espaciais constitutivas da relação pessoa-cultura, como propostas por Boesch (1991) a respeito da ação. Para o autor, "1 - a cultura é um sistema de referências, ou seja, tudo que existe está atrelado a outros objetos e acontecimentos; 2 - é condição si ne qua non da ação o agente estar inserido na cultura; 3- ao agir, o agente busca para si e para situação estados futuros diferentes daquele em que vive no ato da ação." (Sampaio \& Gonçalves, 2017, p. 110). Ou seja, os fluxos simbólicos são elementos com ancoragem espaço-temporal definida, ainda que com contornos nebulosos.

${ }^{4}$ Compuseram a equipe de produção e elenco do espetáculo estudantes que cursavam à época as disciplinas referentes à montagem de formatura e a disciplina Corpo, Expressão e Criatividade, todas sob supervisão do autor deste artigo e integrante do Projeto Político-Pedagógico da Licenciatura em Teatro da Universidade Federal do Tocantins. 
no ano de 2016, sob direção do autor deste texto ${ }^{5}$, como se observa na Figura a seguir:

Figura 1 - Convite do espetáculo Agamenon ou - Quanto vale a vida de um homem?

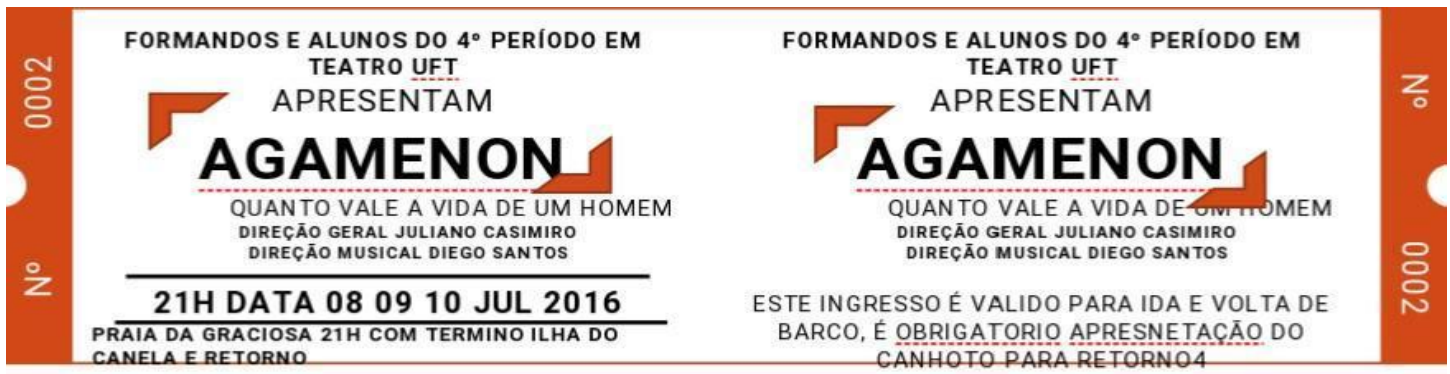

Acervo CONAC-UFT

O espetáculo emerge de dois núcleos temáticos estudados para a finalidade de criação: o mito de Agamenon e a desterritorialização da comunidade do povoado Canela, após a criação da cidade de Palmas (TO). O termo desterritorialização está empregado aqui em relação direta com o conceito de território proposto pela geografia crítica.

Advindo de outras áreas do conhecimento como a Biologia, esse conceito é geralmente tido como um espaço onde o Estado não é o único agente que exerce poder. Nesse espaço, outros grupos sociais também mantêm relações de poder com outros grupos, o que produz e reivindica territórios. Assim, o teatro também seria um agente modificador com a capacidade de produzir novos territórios. O uso do termo se apóia em Haesbaert (2009), para quem os conceitos costumam enfatizar duas grandes dimensões na relação entre espaço e poder: a material e a simbólica. Além de indicar esse espaço concreto e quantificado, o território aparece como um lugar de afetividade, de demarcação e que pode ter importância no processo de fortalecimento do orgulho comunitário." (Braga Junior, 2018, p. 10).

Se o mito constituiu o fio condutor da obra, o dado histórico o organizou simbólica e fisicamente. Os locais para a realização das cenas e as alterações do mito, na construção da narrativa encenada, são frutos desse segundo aspecto de composição do espetáculo em análise e instauram a dimensão site site specific da criação.

${ }^{5}$ Agamenon ou - quanto vale a vida de um homem? - integra o repertório dos espetáculos do Laboratório de Composição Poética Cênica, Narratividade e Construção de Conhecimento (CONAC) da Universidade Federal do Tocantins (UFT). 
Nas artes cênicas, a apropriação do conceito site specific, oriundo das artes visuais nos anos 1970, designa criações/realizações cênicas (teatro, dança ou performance) baseadas em materiais, movimentos corporais, ações, dramaturgias, sonoridades e visualidades que emergem do estreito diálogo dos artistas com as especificidades do lugar escolhido não unicamente como local da apresentação, mas também como meio de criação. (Brantes \& Linke, 2015, p. 113).

Abordaremos a seguir dados históricos do povoado Canela. Após o que, apresentaremos as partes do mito que compuseram o espetáculo evidenciando como a experiência histórica apresentada nos permitiu reelaborar parte da narrativa mitológica.

Figura 2 - Região central do povoado Canela. Antiga Igreja católica e prédio da escola Nossa Senhora do Perpétuo Socorro. Ano: 1993. Foto: Mari lúcia Abreu Lima.

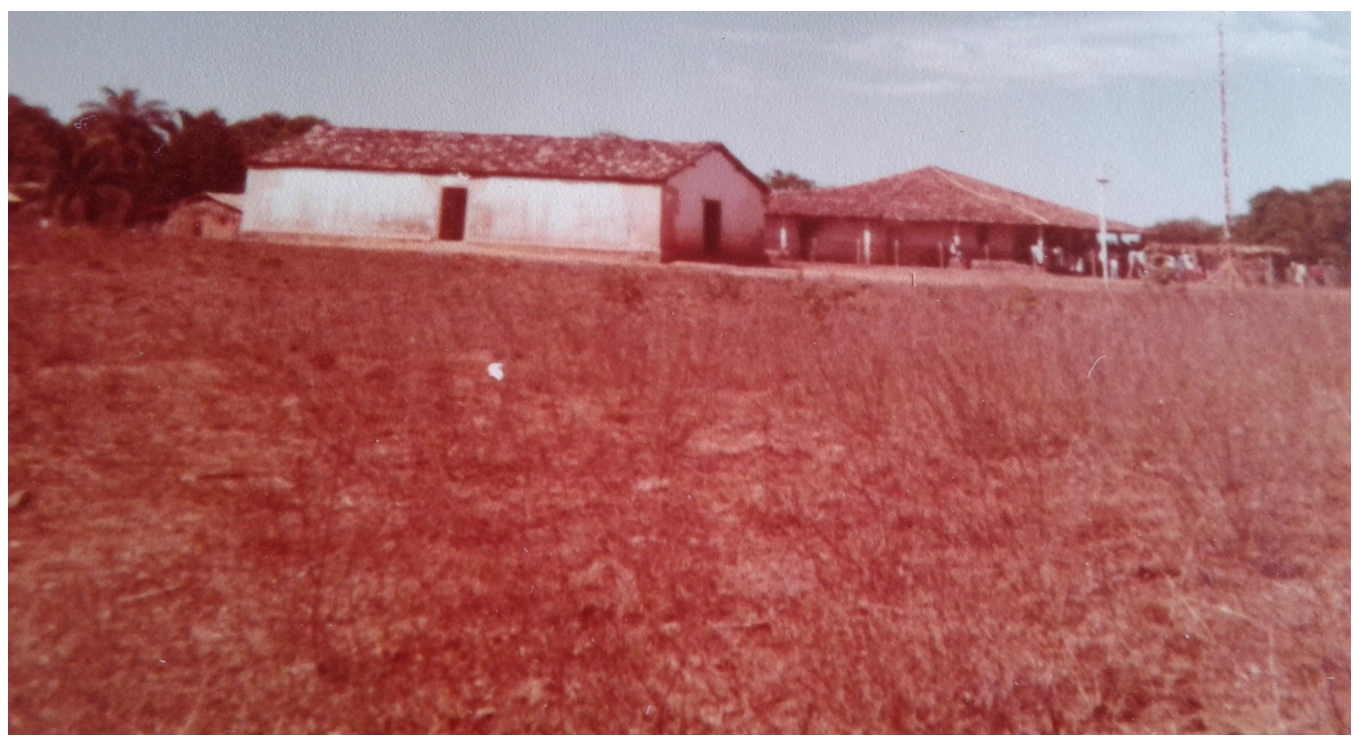

Acervo pessoal de Mari lúcia Abreu Lima

Canela, antes da criação do Estado do Tocantins era um distrito da cidade de Porto Nacional, norte de Goiás (Figura 2). Contudo, “[...] após a criação do Estado do Tocantins em 1988 e de Palmas em 1989 [...]. Canela deixou de ser distrito de Porto Nacional e passou a ser bairro de Palmas" (Lima, 2016, p. 09), capital do Estado em constituição. Na medida em que o volume de pessoas na capital se intensificou, com a chegada de migrantes brasileiros e de fora do país, as necessidades básicas se tornaram urgências sociais, dentre as quais, enfatizamos, a energia elétrica demandada pelos processos de urbanização. Derivou desse 
contexto, e sem debate sociológico e humanitário, a criação da usina hidrelétrica no Rio Tocantins (Figura 3), Usina Luís Eduardo Magalhães, localizada em Lajeado do Tocantins, cidade situada a menos de 80 quilômetros da capital. Essa iniciativa governamental culminou no alagamento das terras antes ocupadas por moradores do povoado Canela.

Figura 3 - Rio Tocantins ante do represamento para a construção da Usina. Trecho entre Porto Nacional e Palmas, Tocantins. Foto: Kátia Maia Flores.

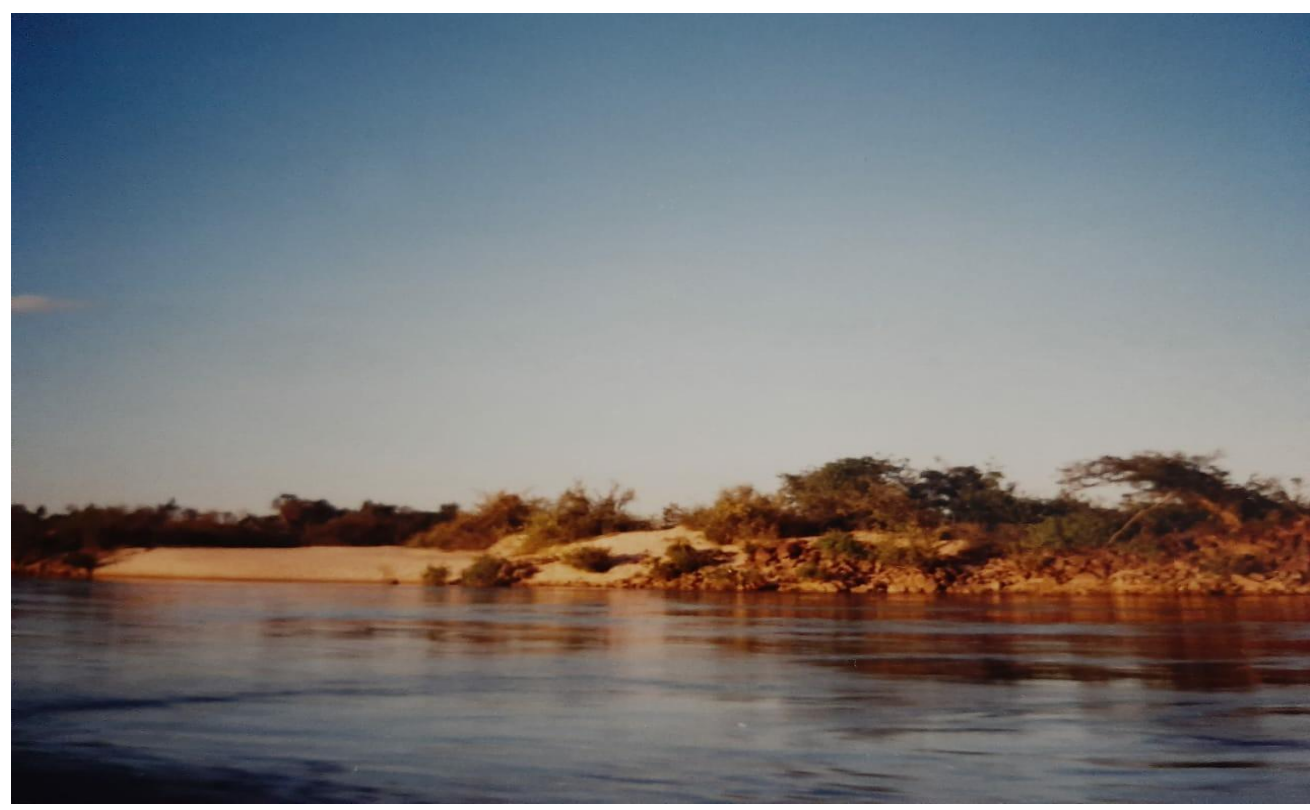

Acervo pessoal de Kátia Maia Flores.

Segundo André (2019, p. 3295),

[...] o governo tocantinense [...] atu[ou] como se a barragem fosse um desdobramento linear da história, portanto, um evento inevitável na cadeia evolutiva da região. Desconsider[ou] qualquer diálogo com a racionalidade sertaneja e jog[ou] seus agentes do outro lado da linha abissal, o lado dos não cidadãos, dos incivilizados, produzindo a não existência da vida sertaneja. A destruição da vida sertaneja d[eu] lugar à vida urbana de modo absoluto. Não se imagin[ou] a possibilidade da coexistência entre elas.

No processo de desterritorialização (alagamento) do povoado, os antigos moradores não receberam indenizações adequadas e de modo igualitário e precisaram empreender longa batalha judicial para serem reassentados em uma 
área que não fosse periférica da cidade de Palmas (TO). Decorre das batalhas judiciais o reassentamento de parte dos moradores do povoado na localidade identificada como Quadra 508 Norte de Palmas (TO), região tida como central no plano diretor da cidade. Esse processo durou mais de dez anos e reordenou os modos de vida conhecidos pela comunidade (Lima, 2016). Sobre esse processo de desterritorialização e reassentamento, o depoimento da ex-moradora do Canela, Marli Abreu Lima, com 52 anos à época, para a também ex-moradora do Canela, Marilucia Abreu Lima (2016, p.14), é bastante emblemático: “É estranho saber que tive quatro filhos no Canela e ele não existe mais. É como se alguma página da minha história tivesse sido arrancada de mim". ${ }^{6}$ Memórias e depoimentos como esses permitiram a André (2018, p. 74) afirmar que "o centro histórico de Palmas está submerso no lago".

Paralelamente ao processo de afogamento do povoado, temos o surgimento de uma itha. O terreno daquela que hoje é conhecida como Itha Canela e explorada comercialmente com visitações para banhos e consumo de alimentos no restaurante ali construído, o terreno localiza-se a aproximadamente 3 quilômetros do que um dia foi o povoado Canela. A utilização do nome Canela por seu proprietário cria a ilusão para muitos frequentadores de que naquela região se encontrava o povoado Canela.

A "emersão da ilha" conta com dois movimentos constitutivos: 1 - as dragas que trabalhavam no processo de formação do lago, decorrente da criação da usina, despejavam terra no terreno em que hoje se reconhece como ilha. Com isso, o terreno teve altitude suficiente para não ser completamente submerso quando da formação do lago; 2 - acréscimo de terras por parte do proprietário para adequar a ilha à presença de turistas e ao uso comercial da mesma. Vale ressaltar que o proprietário da ilha não era morador do povoado Canela e em momento algum, segundo os antigos moradores do povoado, o uso comercial da ilha reverteu-se em benefícios aos antigos moradores do Canela.

A referida ilha foi escolhida pela produção do espetáculo para ser o último espaço físico em que se constituiriam os espaços de representação. O espetáculo

${ }^{6}$ Depoimento que coaduna com a fala final do espetáculo, como se verá no decorrer deste texto. 
possuía três diferentes espaços de encenação: a praia da Graciosa, que está localizada na parte urbana da cidade de Palmas (TO) (início do espetáculo), o barco que adentrava o lago (resultante da construção da usina) e transportava elenco e público até a ilha (meio do espetáculo) e a Ilha Canela (final do espetáculo). A parte inicial do espetáculo compreendia: a) sacrifício de Ifigênia; treinamento de tropas; conversas com as/os Deusas/es e embarque das tropas para a guerra. Todas as pessoas presentes na Praia da Graciosa, bastante movimentada nos períodos de seca no Tocantins, e que serve como lugar para encontros, banho nas águas do lago, prática de esportes, alimentação etc., podiam participar, integrando os exércitos em cena ou assistindo sem interação direta com atrizes e atores. A segunda parte, que compreendia a travessia por barco, como ilustra a Figura 4, constituía-se de consulta aos oráculos e descontração pré-guerra, com bebidas, comidas e quedas de braço entre atrizes e atores e público em geral. A última parte do espetáculo, que se dava na Itha Canela, constituiu-se de Guerra, conversa com os deuses, reencontro de Agamenon e Clitemnestra e julgamento de Agamenon. Essa estrutura nos servirá como guia para a discussão que faremos no decorrer deste artigo sobre a afetação mútua entre o espaço de representação, a fisicidade do espaço cotidiano e os fluxos simbólicos e imaginários sobre o lugar na composição da obra e para a descolonização dos imaginários.

\section{Figura 4 - Barco utilizado no espetáculo Agamenon ou - Quanto vale a vida de um homem?} Foto de Eusete Vitoriano

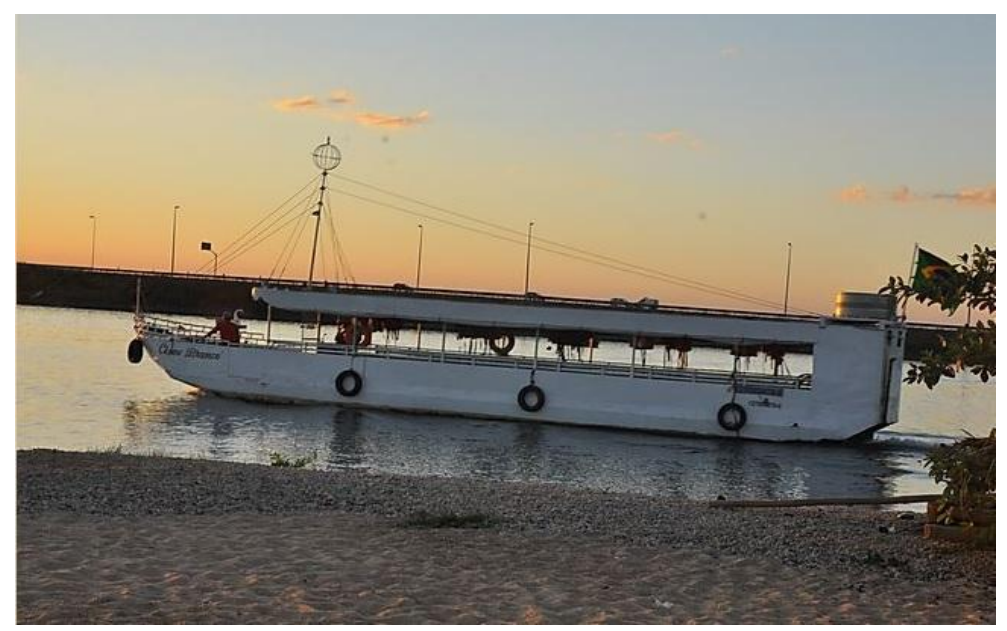

Acervo do CONAC - UFT 
Vale ressaltar que as composições constitutivas e ordenações das três partes do espetáculo se estruturaram a partir de estudo, compreensão e adaptação do mito de Agamenon em articulação com conhecimentos históricos a respeito do povoado Canela. Segundo a narrativa mítica, Agamenon

[...] havia oferecido sua própria filha Ifigênia em sacrifício à deusa Árthemis, nas plagas de Áulis, a fim de reparar uma impiedade ali cometida contra ela, e poder retirar o interdito da mesma, que, por causa dessa hýbris, extinguiu os ventos necessários para que as naus aqueias se dirigissem às praias troianas. (Rufino \& Rufino, 2013, p. 17).

A principal guerra que compõe o mito se inicia quando Páris, após uma missão diplomática em relação aos aqueus, acompanhado por Heitor, leva consigo para Tróia Helena, que foi casada com Menelau, rei de Esparta. Menelau declara guerra aos troianos e busca apoio dos diferentes líderes aqueus. Agamenon, irmão de Menelau, torna-se o mais importante comandante das tropas gregas (aqueus), sendo Áquiles o mais importante entre os guerreiros. Áquiles aceita participar da guerra somente após o convite de Odisseu, devido ao prestígio desse entre os aqueus. Os aqueus liderados por Agamenon ganham a Guerra de Tróia. Ao regressar da guerra, Agamenon traz consigo Cassandra, filha de Príamo, como conquista de guerra. Assim como Agamenon, Cassandra é morta por Clitemnestra. ${ }^{7}$

A tragédia de Ésquilo, Agamenon, inicia com o retorno da personagem título à sua casa "após dez anos de duros combates frente à armada de Tróia, e percorrerá a encruzilhada de várias reflexões sobre a relação entre dever e Justiça, culminando com o assassínio de Agamêmnon" (Rufino \& Rufini, 2013, p. 17). O fato que sustenta a tragédia de Ésquilo é a morte de Agamenon, que chega a ser narrada duas vezes: "a primeira, por meio da previsão de Cassandra, e a segunda, quando Clitemnestra narra como matou o marido". (Bruno, 2013, p. 59).

A escolha por assumir o mito de Agamenon e a tragédia que dele deriva como fio condutor para nos aproximarmos das memórias e histórias do povoado Canela e de seus moradores, se dá em razão de que 
[...] a maioria das tragédias dirige suas atenções para a representação crítica da condição humana, extremamente contraditória e imprevisível, enfatizando as dificuldades que os homens enfrentam no esforço de estabelecer uma boa convivência consigo mesmo e com seus iguais. (Rufino \& Rufini, 2013, p. 14).

Para o autor, a tragédia não tem necessidade ou compromisso de se manter presa ao mito. Ela parte dele e se organiza segundo interesses próprios. Nessa direção, ainda segundo Lanza, foi Ésquilo quem atribuiu à ação trágica a dimensão da escolha humana. Aspecto que nos interessa particularmente quando pensamos o processo de afogamento do povoado Canela e como esse dado simbólico e histórico adentrou a encenação que fizemos de Agamenon. Fica evidente na argumentação do autor que a complexidade da ação trágica está exatamente no ponto de decisão da pessoa humana. Conflitos o arrastam a fazer escolhas ou abandoná-las de modo que uma e outra das opções teriam consequências trágicas, ainda que consequências diferentes em cada um dos casos. Isso significa que a pessoa é devolvida a si, à sua interioridade e não como "Ele ou Tu, ao modo do épos ou da lírica." (Snell apud, Lanza, 2013, p. 87).

A aproximação que víamos inicialmente no campo simbólico entre a tragédia Agamenon, e seu mito constituinte, e a história do povoado Canela, assim, esteve pautada na ideia de sacrifício e consequências trágicas, que reconhecemos na história dos canelenses e que Torrano (1997) indica como princípios motores da tragédia de Ésquilo, somados à prática de crimes hediondos. O entretecimento entre realidade e ficção, mito e história, narrativa e ação, constituíram o espaço simbólico da encenação - fluxos imaginários do lugar. Tais fluxos se tornam caros a nós na medida em que assumimos que "o teatro é atravessado por questões sociais e políticas, a geografia da arte, a política da escrita, os processos de decisão, os discursos dos espectadores." (Bident, 2016, p. 53).

Em Agamenon ou - quanto vale a vida de um homem?, Helena é uma terra, a terra dos Canela, e não uma mulher, como na história de Homero. Vale ressaltar que Páris, no mito, está em uma missão diplomática quando leva consigo Helena. Também a população Canela sofreu os impactos de uma suposta missão diplomática em prol do desenvolvimento quando da criação da usina. Na 
encenação, o sacrifício de Ifigênia se consuma com o afogamento da menina nas águas do lago. Águas que antes irrigavam terras produtivas para cultivo, serviam para o banho e para a limpeza, no espetáculo assumiram-se como veículo da morte (sacrificial). Metaforicamente morreram afogadas ali muitas/os canelenses. Os barcos, que antes eram meios de subsistência (pesca e transporte), na peça eram os "meios da guerra".

Se na história da construção de Palmas (TO), voltar para a terra, para sua cultura, para sua rotina, é/era desejo do povo Canela, para Agamenon, voltar para a casa (Ilha Canela), um território que não é mais seu, e que nunca foi, já que a Itha não se situa no antigo povoado, evidenciou que independente de qualquer justiça que se faça, as consequências pelos atos inescrupulosos já são nefastas para o povo como um todo. E que todo aquele que se beneficiou com a guerra simbólica, no caso dos Canela, em nome do progresso, tal como o proprietário da ilha, posse essa representada como Cassandra no espetáculo, mesmo que tenha conquistado para si algo que julga valioso (para Agamenon, Cassandra), carregará sempre o peso histórico de ter seus ganhos depositados sobre uma comunidade afogada (sacrificada). Cabe a nós conhecedores da história algum posicionamento ou retratação?

Clitemnestra: Agora me olham com olhar de desterro e cólera?

Querem que eu vos relembre quem foi este homem?

Digam-me, quem não condiz com minha vingança, permaneça em seu lugar. Mas quem comigo, apoiando a vingança de uma mãe, pelos dias insuportáveis de dores pela ausência de uma filha e da minha terra; das lembranças que tinha dela e que me foram arrancadas com o tempo... ${ }^{8}$ Vamos, quem está comigo, com essa terra, dê um passo à frente. Pois se todos aqui são juízes, alguém há de me responder: Quanto vale a vida de um homem?

(Fala final do espetáculo Agamenon ou - quanto vale a vida de um homem?)

8 Tomamos aqui a liberdade de utilizar pela segunda vez um trecho de entrevista de que já nos valemos em momento anterior neste artigo, para que a/o leitor/a identifique a analogia das narrativas e sentimentos que nelas se fazem evidentes na interconexão entre realidade e ficção: "É estranho saber que tive quatro filhos no Canela e ele não existe mais. É como se alguma página da minha história tivesse sido arrancada de mim”. (Lima, 2016, p. 14). 


\section{Ato I - As cenas se passam na Praia da Graciosa}

Corpos dispostos na Praia da Graciosa, de maneira não habitual, como pode ser visto na Figura 5, questionam alguns passantes a respeito do que possa estar acontecendo na areia perto do lago. Outras pessoas, espectadoras voluntárias, já que foram à praia para acompanhar o espetáculo, ampliam a proporção dos corpos com vínculo cênico naquele espaço.

Figura 5 - Começo do espetáculo: Agamenon ou - Quanto vale a vida de um homem? Na praia da Graciosa, Palmas (TO). Foto: Eusete Vitoriano

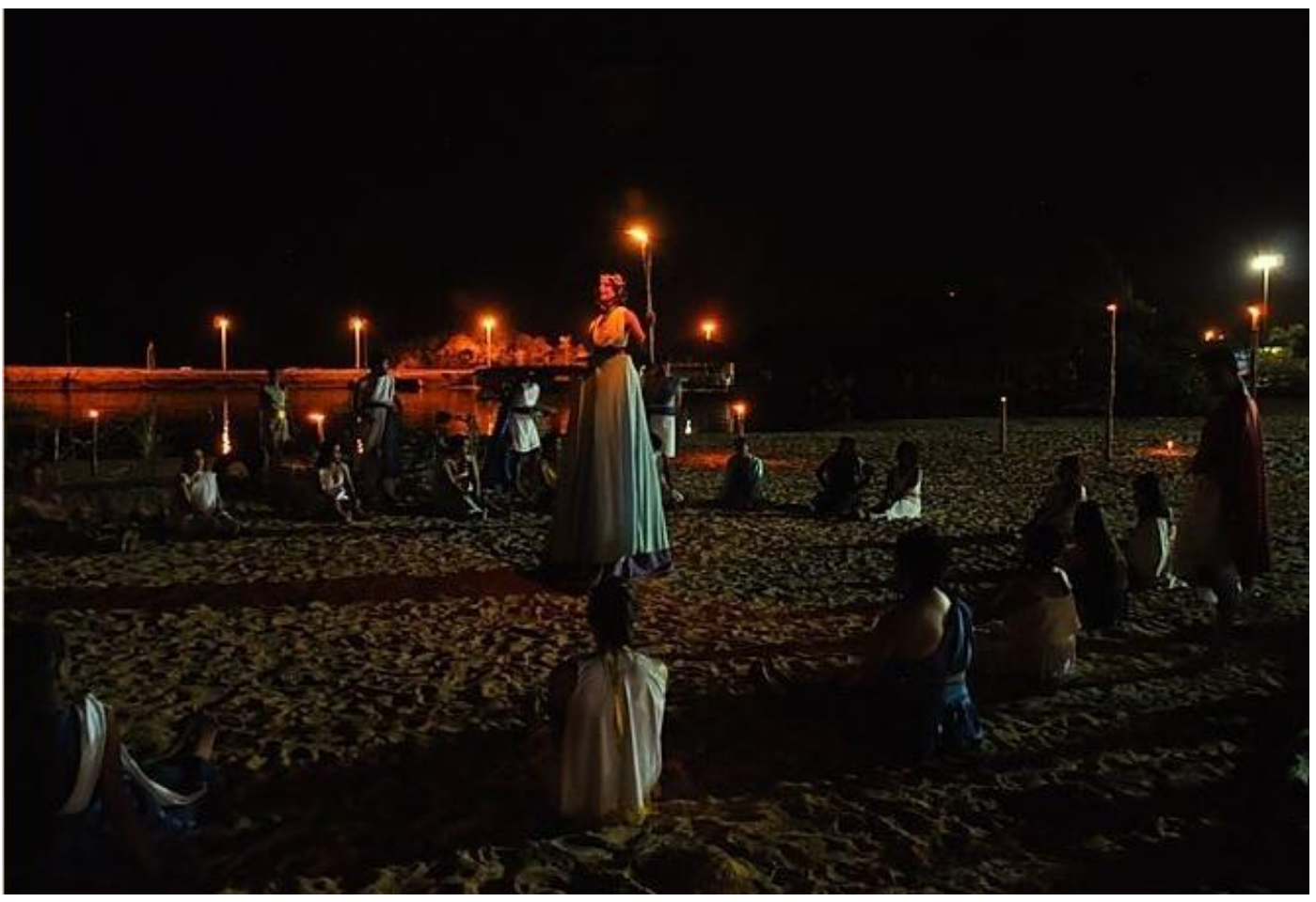

Acervo do CONAC - UFT

Duas naturezas diferentes de público, espontâneo e voluntário, tensionam de saída, a costumeira ideia de ir ao teatro. Como afirma Bident (2016, p. 53), "o último meio século viu, pelo mundo afora, o teatro sair do teatro e desenvolver uma descrença necessária em relação ao edifício fechado com antigos palcos, à cena frontal e à sala escura." É como se, em certa medida, o teatro viesse também até nós e rompesse a mais comum das relações das pessoas com o fenômeno teatral, muitas vezes confundida com a relação do teatro com seu espaço físico. Como 
afirmam Brantes e Linke (2015, p. 111), “[...] o local virou sinônimo do acontecimento teatral. A frase 'Vamos ao Teatro!' implica tanto o local físico como o evento teatral."

Em considerável parte das vezes, pelo que percebemos à época e nos lembramos agora, o segundo grupo de pessoas explicitava ao primeiro grupo que se tratava do espetáculo Agamenon ou - quanto vale a vida de um homem? Nossa presença física naquele momento já era suficiente para alterar as relações (envolvendo interação e conversa) entre público espontâneo e público voluntário. Essa primeira observação, gerada apenas pela presença de corpos de modos não habituais naquele espaço nos permite afirmar que os fluxos simbólicos sobre o lugar são inevitáveis e que

[...] [se] olhar[mos] para o espaço como conjunto de corpos - no sentido dos estóicos - que tem como consequência a interação do ator com um espaço pensado como possuidor de uma energia vital [..], o resultado nas ações teatrais no espaço urbano seria uma negociação, não uma manipulação do espaço, dito de outra maneira, não o ator no espaço, mas o ator com o espaço. (Pérez \& Massa, 2014, p. 4).

O espetáculo se iniciava com uma referência simbólica da relação entre o fogo, o conhecimento, o desenvolvimento tido como necessário e inevitável e as consequências que podem derivar daí. Se por um lado temos clara referência à mitologia, por outro, estamos imersos na história dos canelenses e os sacrifícios que foram obrigados a fazer em prol do desenvolvimento da região, como narramos em parte anterior desse mesmo texto. Agamenon, como se vê na Figura 6, atira uma flecha pegando fogo na direção da corça sagrada, a mata, e temos o início do caos. Os ventos param e o sacrifício de Ifigênia se faz necessário para que os barcos possam navegar. 
Figura 6 - Momento em que com Agamenon mata a corça sagrada no espetáculo Agamenon ou - Quanto vale a vida de um homem? Na praia da Graciosa, Palmas (TO).

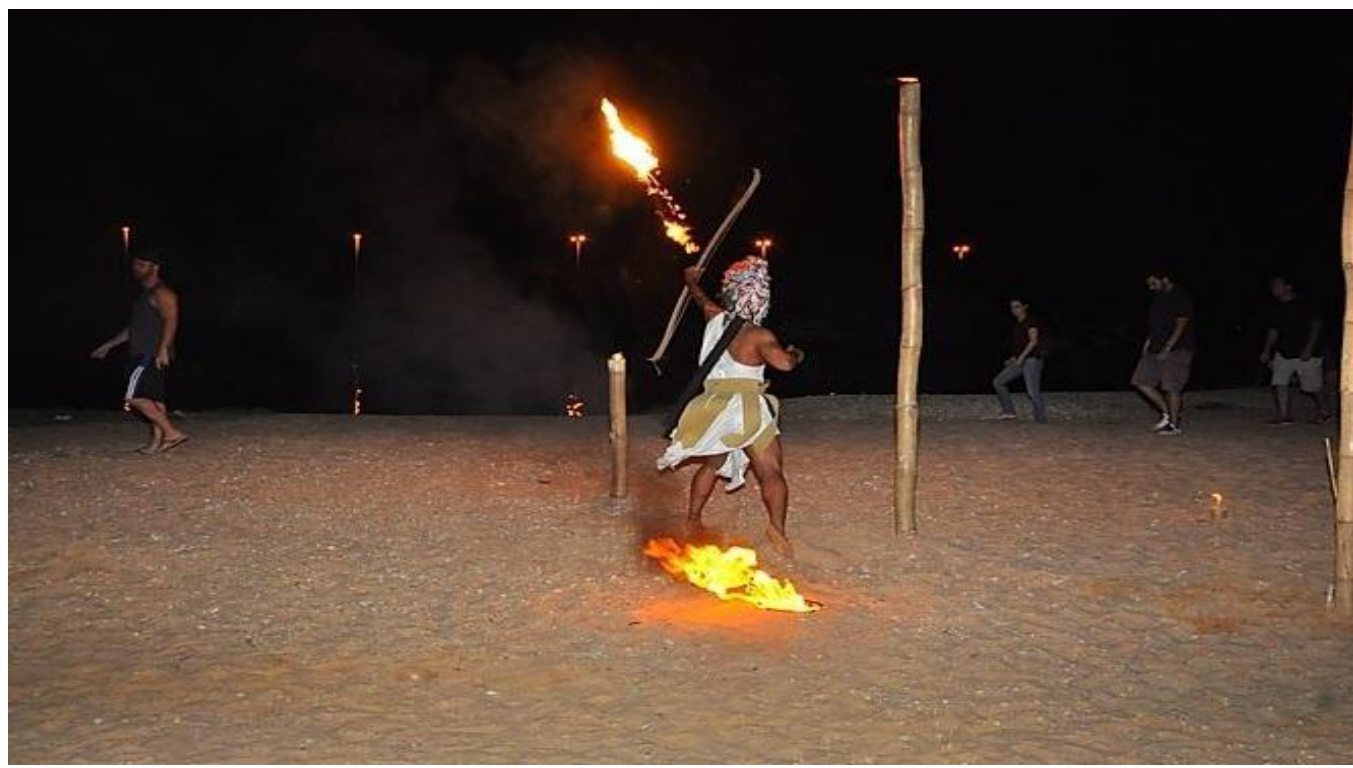

Foto: Eusete Vitoriano. Acervo do CONAC - UFT

No trecho narrado, que envolve fluxos simbólicos, parte da articulação do mito com a história dos canelenses não é evidenciada ao público. Naquele momento, poucos espectadores seriam capazes de reconhecer na ação de Agamenon alguma relação com o povoado Canela. Muito mais provável que acessassem narrativas mitológicas. Esse aspecto se faz necessário nessa discussão, porque nos chama a atenção para o fato de que os fluxos simbólicos que organizam nossas relações espaço-corporais no teatro, no sentido de lugar, possuem pelo menos 3 dimensões: aquilo que interfere diretamente na criação das/os artistas, mas chega indiretamente ao público (ele não acessa o fluxo em si, mas o que decorre dele, como imagem e sonoridade cênicas); 2 - aquilo que interfere diretamente na criação das/os artistas e é acessado pelo público, como por exemplo a troca referencial que fizemos em relação ao motivo da guerra. Se no mito Helena é uma Mulher, na dramaturgia criada ela é "Helena, a terra

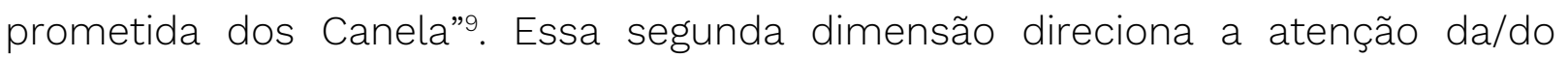
espectador/a para o aspecto do fluxo simbólico e imaginário que interessa aos

\footnotetext{
9 Trecho da dramaturgia do espetáculo.
} 
sentidos e significados pretendidos com o espetáculo; 3 - já a terceira dimensão se refere a aquilo que não é suposto pelas/os artistas, mas é acessado pelo público, dado conhecimentos que possuem e que escapem aos criadores.

Apostamos nessas três dimensões, quando estamos trabalhando no âmbito do teatro site specific, como cruciais para a passagem da fisicidade das relações e do espaço de representação à instauração do lugar simbólico do espetáculo, que assumimos, em suma, como o espaço praticado, operado pela linguagem teatral.

[...] antropólogos, sociólogos e urbanistas contemporâneos afirmam que a cidade não é arquitetura, mas o que acontece nessa arquitetura; isso que Certeau (2000) vai chamar de espaço praticado, o espaço ativado através do corpo. Assim, na ideia de cidade se tem também uma definição representativa do espaço e uma definição expressiva dele. (Pérez \& Massa, 2014, p. 2).

A primeira dimensão, aquela intencionada na criação pela/o artista, mas não acessada como tal pela/o espectador/a, constitui-se muito mais como um convite para relações exóticas aos usos condicionados da cidade. O sacrifício de Ifigênia é consumado no espetáculo pelo afogamento (representacional) de uma atriz por um ator do grupo nas águas do lago, como se observa na Figura 7. Como fluxo simbólico do lugar no âmbito da criação, o lago representa para as/os criadoras/es o afogamento de uma comunidade inteira em prol de algo que é tido como positivo (desenvolvimento) por um grupo externo ao povoado. As referências, cada vez mais frequentes no espetáculo ao povoado Canela, tem por função, para o encenador, possibilitar questionar o imaginário de espectadores a respeito do lago (descolonização de imaginário). Quase sempre tido como espaço para diversão, esquece-se facilmente da tragédia que envolve sua formação. Na medida em que problematizamos as imagens em relação ao lago, por exemplo, buscamos transitar entre essa dimensão do fluxo simbólico do lugar e aquela em que criadoras/es e público passam a compartilhar dos mesmos fluxos ou de fluxos análogos. Afinal, como afirmam Pérez e Massa (2014, p. 4), "A cidade se constrói continuamente, não só na imagem, mas no imaginário dos habitantes". 
Figura 7 - Afogamento (sacrifício) de Ifigênia por Agamenon no espetáculo Agamenon ou Quanto vale a vida de um homem?, no lago que banha a praia da Graciosa, Palmas (TO).

Foto: Eusete Vitoriano

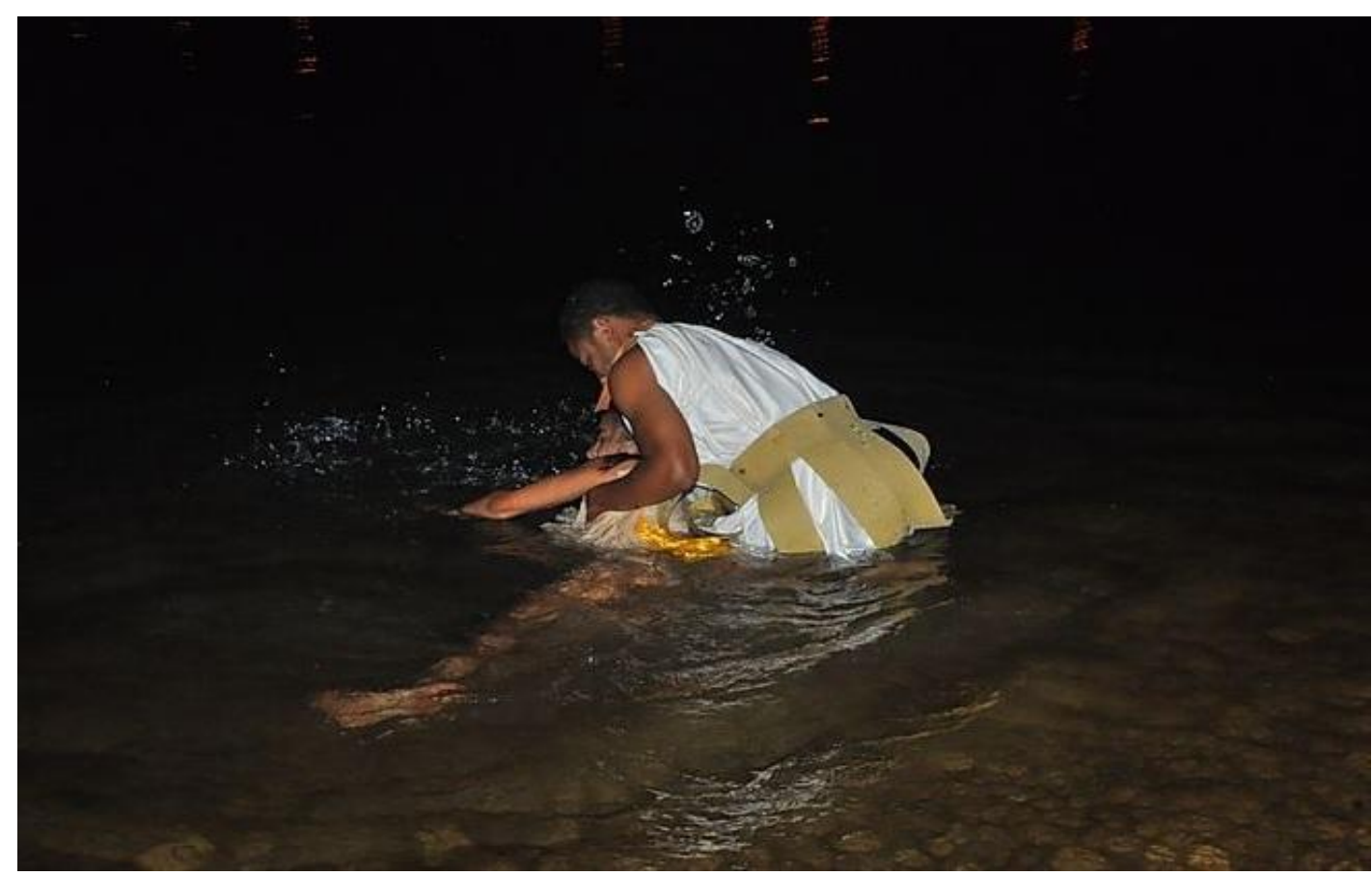

Acervo do CONAC - UFT

Reiniciados os ventos ficcionais, por ação divina, ventos reais que sopram intensamente em Palmas (TO) nos meses em que o espetáculo foi apresentado, o elenco se divide em dois grupos para a preparação para a guerra. Nesse momento as classificações provisórias de público espontâneo e voluntário se dissolvem e outra divisão se instaura: duas trincheiras pré-construídas na Praia da Graciosa para o espetáculo abrigam atrizes e atores e pessoas do público que queiram se juntar a elas/es. Um pouco mais distante permanecem as pessoas do público que preferiram não se entrincheirar. Os diálogos que se davam em cada trincheira só podiam ser ouvidos por quem estava na trincheira e pelo público próximo. Na mesma direção de tantos outros espetáculos teatrais site specific, a nossa composição do espaço de representação nesse caso específico caminhava na direção da noção de que

[...] muitas das ações teatrais nos espaços da cidade mais do que transmitir uma mensagem, tentam oferecer experiências que surgem do acontecido entre o espectador e todos esses outros corpos agindo na 
encenação, o que dá lugar a uma troca de intensidades. (Pérez \& Massa, 2014, p. 4).

Após a retirada dos canelenses do seu território e assentamento de parte dos mesmos na quadra 508 Norte (Palmas - TO), os antigos moradores do povoado entraram em contato e em muitos conflitos com diferentes manifestações culturais. Uma delas foi a capoeira. Prática que não era presente no povoado, segundo relatos de canelenses, passou a integrar o cotidiano das escolas e da comunidade. Optamos por trazer a roda de capoeira para o espetáculo como menção da luta pessoal e coletiva dos canelenses para se adaptar ao novo território, sem perder a referência às antigas tradições. No espetáculo a roda de capoeira nos servia como interação com o público, como elemento subjetivo de algumas atrizes e atores que tinham forte envolvimento com a capoeira, preparação para a guerra fictícia e seguia na direção do que aponta Icle (2013, p. 181): as "[...] práticas cênicas brasileiras [...] nos últimos anos insistem em mesclar teatro e dança; performance e ritual; ópera e circo; manifestações de rua e de sala; entre inúmeras outras possibilidades."

Se os fluxos simbólicos do lugar emergem da relação entre o mito, história e o espaço, há ainda que se considerar, como já apontamos, que as práticas e inclinações subjetivas das/os criadoras/es e do coletivo como um todo compõem parte extremamente relevante do trato que damos aos fluxos na criação cênica, desde a perspectiva com que trabalhamos. Exemplos disso são não só a presença da capoeira como também a escolha pela capemba da árvore buriti como escudo de guerra, carregados pelas atrizes e pelos atores. Tal árvore é parte integrante da flora do cerrado e uma imagem facilmente compartilhada pelos moradores da região ${ }^{10}$. Além disso, o buriti era uma importante fonte de renda para os moradores do povoado Canela.

Iniciemos a viagem de barco!

10 Outras cenas compuseram a primeira parte do espetáculo, mas não foram abordadas aqui por motivo de recorte temático. A mesma estratégia será utilizadas quanto as partes intermediária e final da obra, atos II e III. 


\section{Ato II - As cenas se passam no Barco de Guerra}

Após uma marcha acompanhada de canto de guerra da praia até o cais do lago, e de equipar elenco e público com armaduras de guerra (coletes salva-vidas), as pessoas que haviam adquirido antecipadamente o ingresso, eram convidadas a adentrar o barco de guerra. A capacidade de transporte era de até 60 pessoas. Ingressos foram vendidos antecipadamente para cada apresentação. Um número adicional de ingressos era vendido para pessoas que haviam acompanhado a primeira parte do espetáculo e que não tinham feito a compra antecipadamente. Ressaltamos que com essa dinâmica, três naturezas diferentes de percurso de espectador/a culminavam na entrada no barco: 1 - Aqueles que compraram antecipadamente o convite; 2 - aqueles que não possuíam convite, mas que foram voluntariamente para a praia acompanhar o espetáculo e depois compraram o ingresso na entrada do barco; 3 - aqueles que não foram à praia para acompanhar o espetáculo, mas acabaram o fazendo, e adquiriram o convite na entrada do barco. Dois outros conjuntos de espectadores devem ser considerados: 1 - pessoas que não possuíam convite, mas que foram voluntariamente para a praia acompanhar o espetáculo e depois não compraram o ingresso na entrada do barco; 2 - pessoas que não foram à praia para acompanhar o espetáculo, mas acabaram o fazendo, e não adquiriram o convite na entrada do barco. Cinco diferentes relações espectador-espetáculo se erigiram dadas as estruturas da encenação. Tal fato evidencia que as relações entre espaço físico e espaço de representação são muito mais complexas no contexto que abordamos do que se poderia supor em uma aproximação desleixada a respeito do tema.

Nessa direção, Brantes e Linke (2015, p. 113) apontam que:

Ao focalizar as particularidades e usos existentes de um lugar específico em vez de atuar conforme as normas e convenções do palco italiano, da rua, e do espaço alternativo, a cena revela-se como potencial transformador do espaço vivido, acionando possibilidades e/ou impossibilidades de diálogo com os dados de realidades: usos, deslocamentos, reinvenções, apropriações de vestígios e índices de temporalidades e espacialidades que ecoam diversos contextos específicos. 
No barco, os arautos se fazem presentes por meio de danças e performance de uma das atrizes do grupo. Festividades pré-guerra são acontecimentos dos trinta minutos de travessia no lago até a Itha Canela. Vinho e amendoim eram servidos ao público, em canecas feitas de madeiras da região. Disputadas de queda de braço eram realizadas entre elenco, elenco e público, e público entre si. O estado de euforia dominava o barco na medida em que o elenco incentiva o público a beber, comer, jogar, cantar, disputar e se preparar para a guerra.

Estávamos sob o lago e dentro de um barco, que em contextos extra cena são utilizados para festas particulares regadas a banhos no lago, bebidas e música alta. Geralmente durante o dia. O novo contexto se dá à noite, com clima de guerra e rumo à uma experiência desconhecida da maioria. A proposta era intervir nos modos cotidianos de operar com aqueles elementos por e para aquela população. E como afirma André (2016, p. 3286) "Intervir é criar desvios". Desvios nos modos de habitar aqueles espaços e de utilizar aqueles meios de transporte e objetos.

Diferente da primeira parte do espetáculo, o barco como espaço de representação não permite variações do modo de pertencimento físico do público em relação à encenação, ainda que saibamos que o âmbito simbólico varia de pessoa para pessoa. Todas e todos estão inseridas/os e sem possibilidade de sair daquele espaço. As ações do elenco bem próximas ao público revelam uns/umas aos/às outros/as, como se pode ver na Figura 8. Essa experiência coaduna com a proposição de Icle (2013, p. 182) de que "as artes da cena [são] lócus privilegiado para exercer uma atividade bastante humana: estar em presença do outro."

Nesse tocante, é necessário atentar para o fato de que

Ao discutir a questão do lugar, um dos aspectos relevantes está no fato de ele não se encontrar, necessariamente, ligado a uma estrutura edificada determinada. Assim, a utilização do termo lugar teatral deve ser empregada, no sentido geográfico, para todos os lugares nos quais ocorram eventos teatrais. Por conseguinte, o lugar teatral contém, ao mesmo tempo, os condicionantes do espaço teatral e do espaço geográfico. (Almeida Junior, 2007, p. 1). 
Figura 8 - As festividades pré-guerra no espetáculo

Agamenon ou - Quanto vale a vida de um homem?, dentro do barco de transporte, sobre o lago que banha a praia da Graciosa e a Ilha Canela, Palmas (TO).

Público disputa entre si queda de braço. Foto: Eusete Vitoriano.

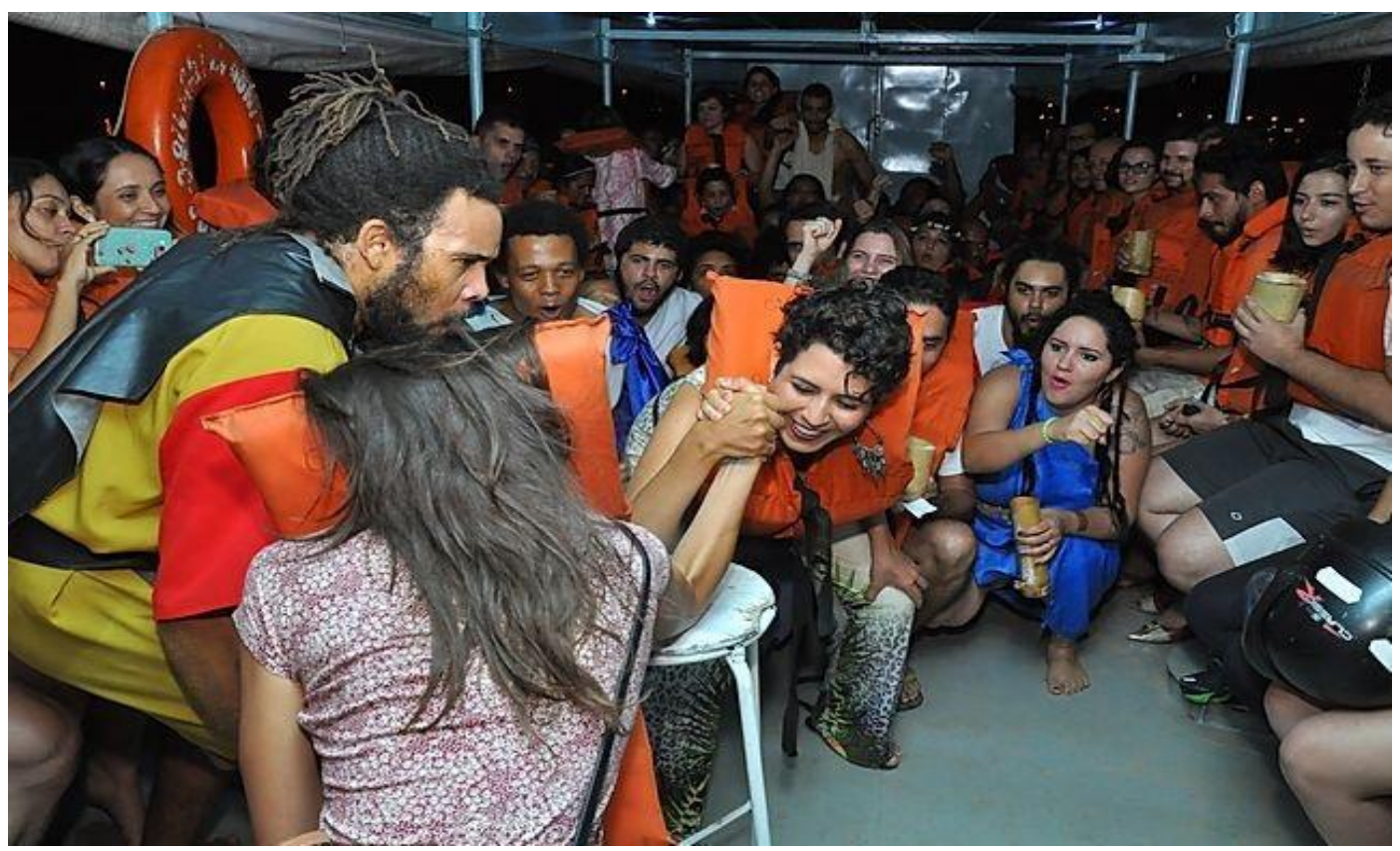

Acervo do CONAC - UFT

O lago, que nas práticas cotidianas em relação à população da cidade é um lugar de divertimento e está associado à sensação de liberdade, dadas as naturezas de atividades ali desenvolvidas, passa a ser símbolo de perigo e prisão. O lago tem grande profundidade e está povoado por piranhas e arraias. É noite, tem-se pouca visibilidade. No meio do trajeto, pequenos barcos chamados de voadeiras, passam ao lado do barco, com parte do elenco segurando lamparinas e emitindo gritos de guerra. Talvez aqui possamos supor, já que sobre ela não temos qualquer controle, a terceira dimensão constitutiva dos fluxos simbólicos que compõem o lugar da cena. Experiências pessoais em relação ao lago, aos medos e prazeres que ele possa gerar, à experiências pessoais de estar em um barco pequeno e com muita gente, o imaginário coletivo a respeito dos naufrágios etc., podem vir a operar os simbolismos da cena.

O trânsito apontado como possível entre as díades segurança-insegurança, divertimento-medo, dia-noite, festa-guerra, são importantes para as/os 
criadoras/es na medida em que podem ser claramente reconhecidas tanto no mito de Agamenon quanto na história dos canelenses. A exemplo, podemos assumir a relação daquele povo com as próprias águas que compõe o lago. Se antes elas representavam, como apontamos anteriormente, lugar de banho, diversão, festividades e subsistência, nos dias atuais representam perdas, mortes, medos, ocultamento cultural (a que associamos à noite) etc..

Na esteira do exposto, podemos recorrer por analogia às observações que se seguem a respeito do espetáculo BR3, realizado pelo Teatro da Vertigem, originalmente na cidade de São Paulo, mais especificamente no Rio Tietê e seus arredores. Segundo Bident (2016, pp. 55-56), Antonio Araújo, diretor daquele espetáculo, com

\begin{abstract}
A "requalificação do rio em espaço teatral" realiza, com isso, um teatro atravessado por sua própria história, pela história do país, por uma constituição dessa história como ficção. Os espectadores são convidados a perceber um lugar que não é nunca percebido como tal e a se interrogar sobre a sua historicidade e a deles próprios.
\end{abstract}

Assim como se reconhece na obra BR3, em relação ao Rio Tietê, nós também, em relação ao lago, "Mais do que ressignificar o rio como espaço teatral, [reconhecemos] a importância de ressensibilização do rio para o espectador" (Audio \& Fernandes apud Bident, 2016, p. 55). A ressensibilização do rio e do lago, cada um em seus respectivos contextos, resulta, para nós, da interconexão das três dimensões abordadas neste texto a respeito dos fluxos simbólico e imaginários sobre a composição do lugar teatral. Ou seja, entretecimento de mito, histórias (dos canelenses e dos espectadores) e espacialidades - sua fisicidade e seus usos (cotidianos e cênicos).

\title{
Ato III - As cenas se passam na Ilha Canela
}

Desembarcados na ilha, elenco e público presenciam guerra e mais conversas com deusas e deuses. Mas nossa atenção se voltará neste texto para a morte de Agamenon. O encontro de si com as consequências trágicas de sua escolha, já que 
naquele momento do espetáculo nos aproximávamos mais da tragédia de Ésquilo. Nesse terceiro momento, na cena final do espetáculo, o público é convidado a observar a ação cênica sem participar ativamente dela. De dentro das águas do lago que cercam a itha que se chama Canela, mulheres semi-imersas esperam pelo retorno daquele que conta e canta suas vitórias, seus progressos e suas conquistas independentemente das consequências.

Agamenon é recebido por Clitemnestra, e demais mulheres do território, como mostra a Figura 9. Ele é levado para dentro do lago, na representação de que sua terra está sob as águas que ele usou para sacrificar sua filha. Lá é morto nessa imensa banheira, enquanto a "Vaca afoga o Touro." Seu corpo é trazido de volta à terra já sem vida sob o canto de mulheres que expressam seu luto. Em uma referência explícita e simbólica ao afogamento do território Canela, destruído pela história do progresso.

Figura 9 - As mulheres Canela esperando a volta de Agamenon para matá-lo afogado no lago, no espetáculo Agamenon ou - Quanto vale a vida de um homem? Itha Canela, Palmas (TO). Foto: Eusete Vitoriano

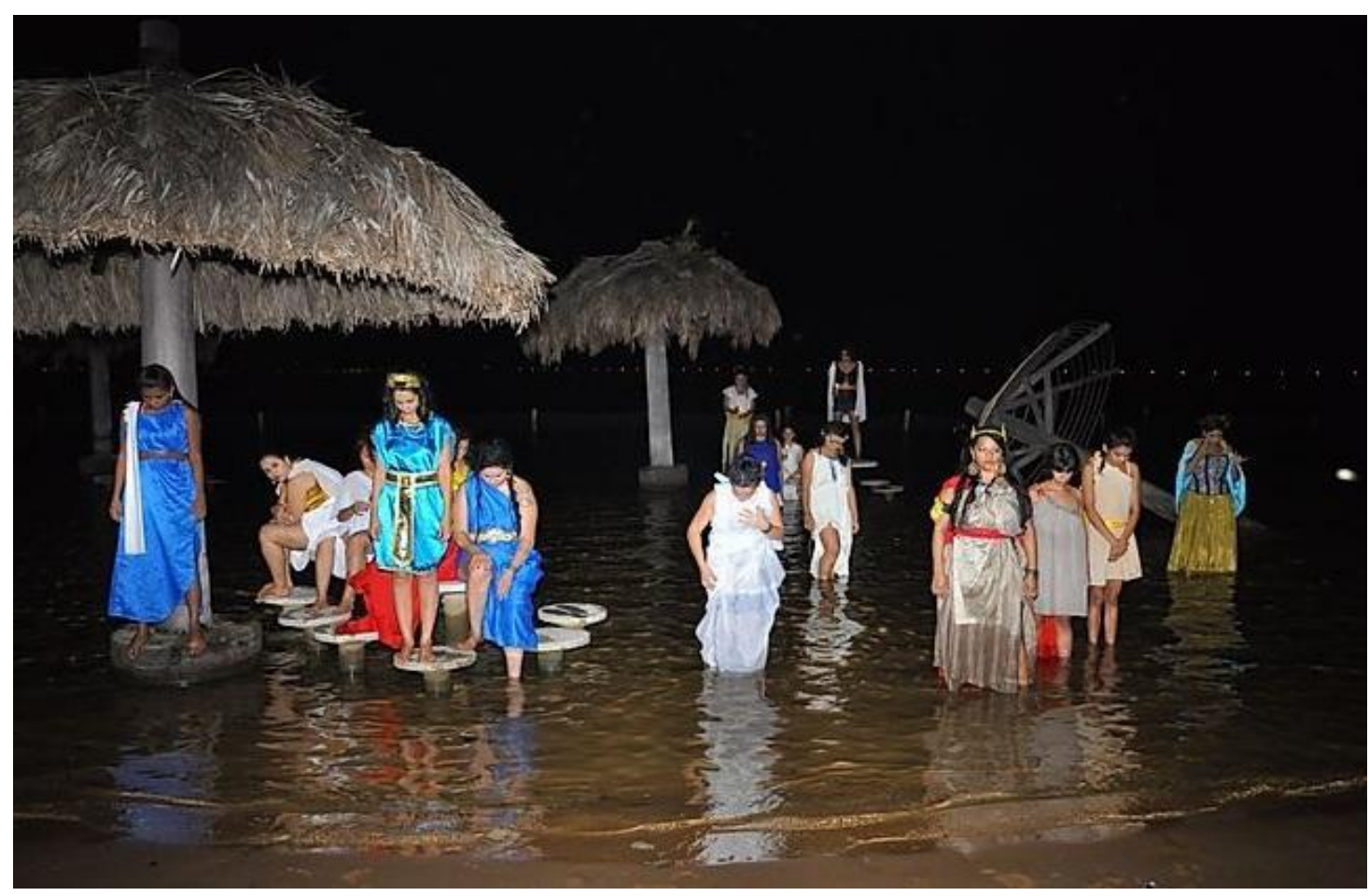

Acervo do CONAC - UFT

${ }^{11}$ Trecho da dramaturgia construída para a cena a partir das análises do mito e da tragédia Agamenon. 
Quando assumimos o povoado Canela como um território que compõe os fluxos simbólicos e imaginários do lugar teatral do espetáculo, estamos considerando as dimensões material e simbólica do Território, como apontamos no início desde texto desde Braga Junior (2018) e desde Boesch (1991). Ou seja, da condição de espaço concreto, em um dado momento, se articulam na cultura as temporalidades e as afetividades da história e das antecipações possíveis das relações da pessoa com aquele espaço concreto, em outros tempos e sob outras condições. Os fluxos simbólicos se articulam, para além das relações vividas, com as possibilidades ainda não vividas ou não mais possíveis de serem vividas pela pessoa naquele espaço concreto, constituindo-se os fluxos imaginários. Nessa direção é que sustentamos que nossas proposições teatrais tendem a ressignificar as relações das pessoas com o lago.

Vale ressaltar que toda essa cena se passava em um espaço que se vale da história dos canelenses e de seu território, a Itha Canela, e faz dela um meio de beneficiamento individual, sem qualquer retribuição ou compensação aos membros do antigo povoado. Temos recordação de pessoas que nos questionavam como o proprietário do local havia nos permitido encenar ali uma crítica tão voraz, de certo modo, a ele próprio. O que ocorreu naquele momento foi que a ele interessa mais pessoas indo à ilha e a nós interessa subverter e ressignificar a relação que se tinha com ela e com a história dos canelenses como um todo. Nos valemos naquele momento do que André (2016, p. 3292), desde Michel de Certeau, reconhece como o modo tático de agir da e com arte em espaços públicos: "ag[ir] no tempo (esper[ar] a ocasião propícia) para agir no espaço para seu próprio interesse."

Na medida em que os fluxos simbólicos e imaginários e os modos táticos de operar na e com a ilha se efetivaram com a encenação é que podemos dizer que ela se tornou um lugar teatral e que a partir de então podemos supor ressignificála a respeito da sua história e de seus usos. Isto porque, "O processo de significação que se desenvolve no lugar teatral deve ser percebido como um fenômeno cultural, visto que ele se dá pelo uso social do lugar. É pela noção de uso de um lugar, então, que temos a denominação lugar teatral." (Almeida Junior, 
2007, p. 2).

Após a finalização da última cena, o público se dividia outra vez em dois grupos: 1 - pessoas que queriam voltar imediatamente para a Praia da Graciosa, transporte que fazíamos com nosso barco; 2 - Pessoas que preferiam passar mais algum tempo na ilha, festejando com a equipe de criação. Festividade que era igualmente presente no povoado Canela.

\section{Cai o pano}

O que apresentamos neste texto, ao analisar o processo de criação e apresentação do espetáculo teatral (Site Specific) Agamenon ou - quanto vale a vida de um homem?, teve por finalidade explicitar como supomos que se dão os fluxos simbólicos e imaginários, na constituição do lugar teatral, quando se tem trânsitos da criação e da obra entre a ficção e a realidade, a fisicidade e o espaço de representação, entre elenco e espectadores.

Resultou dessa análise o reconhecimento de que o lugar teatral tem estreita relação com processos pessoais e coletivos de ressignificação dos espaços, territórios e histórias, de modo a ensejar, na direção do teatro atravessado proposto por Bident (2016), novas formas de subjetivação. Isto porque, a experiência resulta (pelo que se espera e busca) como transformadora dos modos de percepção dos dados históricos, territoriais, afetivos, simbólicos e espaciais que emergem do cotidiano. Nas palavras de Brantes e Linke (2015, p. 114):

A performance em sítio específico, como experiência estética-política dos lugares, instaura modos de reconfiguração do espaço e das fronteiras territoriais, que desestabilizam as categorias de percepção dos participantes (performers e espectadores).

E se consideramos que neste caso específico é do e para o cotidiano que emergem as ressignificações e os modos de perceber as coisas do mundo que compõem os fluxos da encenação, devemos considerar o lugar teatral como "um mediador entre o Mundo e o Indivíduo" (Almeida Junior, 2007, p. 1). Todavia, a 
mediação que esperamos com as proposições dos fluxos simbólicos e imaginários são da ordem da tensão e da fricção. Construímos essa perspectiva da relação mediadora da arte em relação à pessoa e ao mundo, considerando que:

A experiência estética, em todos os casos, deve ser considerada como uma experiência liminar, como a experiência de estar no "entre-dois", assim como exprimiu Victor Turner (1969. p. 95), como uma experiência de crise. É, sobretudo, quando a oposição entre "real" e "ficcional" desaparece que tem lugar a crise. (Fischer-Lichte, 2013, p. 31).

Para encerrar, ainda que não seja o foco desta escrita, gostaríamos de retomar um contexto específico de emergência do espetáculo analisado: a licenciatura em teatro. Esse é outro aspecto dos fluxos que poderia ser considerado na criação do espetáculo em questão. Estávamos à época pensando temáticas e modos de fazer teatro que pudessem ser relevantes e transformadores nas e das relações que se estabelecem em instituições de ensino. Buscávamos, pela experiência desta criação, propiciar às/aos licenciandas/os em teatro, supor temas e modos de operar com teatro os mundos de futuros estudantes com quem e para quem se dedicarão enquanto professoras/es. Outros aspectos das relações entre espaço e lugar, ficção e realidade, devem ocupar dimensão privilegiada no ensino de teatro, em especial quando olhamos para a educação básica, pública e periférica. Certamente ter isso em mente nos fez optar por certos modos de fazer e operar a criação e as cenas do espetáculo, o que seria passível de análise em outro contexto.

\section{Referências}

ALMEIDA JUNIOR, José Simões. Considerações acerca do conceito de lugar teatral. Anais da IV Reunião Científica de Pesquisa e Pós-Graduação em Artes Cênicas, v.8 n.1, p. 1-4, 2007.

ANDRÉ, Carminda Mendes. O centro histórico de Palmas. In: FLORES, Kátia Maia; ANDRADE, Karyleila; ANDRÉ, Carminda Mendes (Orgas.). Educação, Interculturalidade e outros debates. Goiânia: Editora Espaço Acadêmico, 2018, p. 73-94. 
ANDRÉ, Carminda Mendes. Intervenção Urbana como Tática Pedagógica: encontro com foliões. Em: Anais do IX Congresso da ABRACE - Poéticas e Estéticas Descoloniais - Artes Cênicas em Campo Expandido, v.1, n. 1, p. 3284-3308, 2016.

BIDENT, Christophe. O teatro atravessado. Art Research Journal, v. 3, n. 1, p. 50-64, 2016.

BOESCH, Ernest. Symbolic Action Theory and Cultural Psychology. Berlim Heidelberg Nova York: Springer,1991.

BRAGA JUNIOR, Jorge Roberto Ribeiro. O teatro atravessado pelo território no teatro do Grupo Código. Anais ABRACE, v.19, n.1, p. 1-21, 2018.

BRANTES, Eloisa; LINKE, Ines. Diálogos (Im)Possíveis: espaços e lugares da cena. ASACT, v.1, n. 1 p. 110-124, 2015.

BRUNO, Pauliane Targino da Silva. Do Mito à Tragédia: Agamêmnon entre a Grécia e Roma. Dissertação de Mestrado. Mestrado em Letras. Universidade Federal do Ceará. 2013.

FICHER-LICHTE, Erika. Realidade e Ficção no teatro contemporâneo. Sala Preta, São Paulo, v.13, n.2 , p. 14-32, 2013.

HOMERO. Ilíada. São Paulo: Penguin Classics Companhia das Letras, 2013.

ICLE, Gilberto. Vontade de presença, vontade de corpo: para pensar o teatro brasileiro contemporâneo. Sala Preta, São Paulo, v.13, n.2 , p. 180-192, 2013.

LANZA, Diego. A dramatização do mito. Kriterion, Belo Horizonte, v. 44, n. 107, p. 86-99, 2003.

LIMA, Evelyn Furquim Werneck. Espaço Teatral e Performatividade. Estratégias e táticas na cena moderna e contemporânea. Urdimento, n. 11, dezembro-2008.

LIMA, Marilucia Abreu. Movimentando Memórias: teatro documentário sobre o povoado Canela do Tocantins. Trabalho de Conclusão de Curso. Licenciatura em Teatro. Universidade Federal do Tocantins, 2016.

PAVIS, Patrice. A análise dos espetáculos. São Paulo: Perspectiva, 2003.

PÉREZ, Claudia Edith; MASSA, Clóvis Dias. A cidade como cenário corporizado. Anais ABRACE, v. 15, n. 1, p. 1-6, 2014.

RUFINO, Emmanoel de Almeida; RUFINO, Eduardo de Almeida. Mito e justiça na tragédia Agamêmnon de Ésquilo. Olho d'água, São José do Rio Preto, v. 5, n.2, p. 1-263, 2013. 
TORRANO, Jaa. Mito e violência na tragédia em Agamêmnon de Ésquilo. Letras Clássicas, v. 1 n. 1, p 29-37, 1997.

SAMPAIO, Juliano Casimiro de Camargo; GONÇALVES, Amanda Diniz. Experiência Corporal Estética. Revista Moringa - Artes do Espetáculo, João Pessoa, UFPB, v. 8 n. 2, p.109-124, 2017.

Recebido em: 29/06/2020

Aprovado em: 09/07/2020 